\title{
Editorial
}

\section{Hospital de Ensino Odontológico- tradução de 120 anos de excelência}

Ao ser convidada a escrever sobre o aniversário de 120 anos da nossa Faculdade de Odontologia da UFRGS, ocorre-me que esta Instituição sempre esteve fortemente presente em minha vida, bem antes da trajetória como aluna e professora. Para abrir a reflexão, preciso transcrever meu padrinho José Chaher, Diretor de nossa Faculdade por ocasião de nosso 560 aniversário: "A vida de uma casa de ensino é sempre uma história que se desenrola. Na história da vida, como no curso próprio dos fenômenos naturais, não há improvisações, não há precipitações, nem problemas insolúveis. Os fatos novos, onde atualmente se desenvolveram ideias e aspirações antigas, são fruto de uma longa fase de maturação das tendências profundas de um passado que não se extinguiu. Todo fato embora encarado em seu aspecto atual, estende no tempo e no espaço, prolongamentos que nos dão a ideia exata de cada instante que passa, e de cada intenção que avança em direção do porvir. O presente sem passado não tem sentido. O passado sem o presente não tem vida." Ou as palavras de meu pai, João Jorge Diniz Barbachan, outro Diretor de nossa escola, por ocasião de nosso 100o aniversário: “A trilha do tempo, percorrida até aqui, revela-nos que somos capazes de superar as dificuldades e as crises que envolveram e envolvem, a instituição federal de ensino superior. Somos capazes de desempenhar nosso papel social relevante, qual seja: o ensino, a pesquisa e a extensão, que foram os objetivos desta casa. Metas, algumas vezes, atingidas a duras penas, mediante sacrifícios pessoais de seus docentes, discentes e técnicos administrativos." Ao refletir sobre o nosso momento atual, o aniversário de 120 anos de existência de uma instituição de excelência como a nossa, não pude deixar de aproveitar as palavras de nossos antecessores. Não podemos nos vangloriar do nosso presente, sem saber que este é fruto de toda uma história viva, que inclui uma sucessão de fatos e personagens que construíram o que temos e somos hoje. Nossa trajetória deve encher de orgulho a cada um de nós que fez ou faz atualmente parte dela. Este sentimento de júbilo, concretiza-se hoje quando observamos nossos 144 espaços de atendimento odontológico da mais alta qualidade. Atrevo-me inclusive a afirmar que nosso trabalho de 120 anos de atuação qualificada está refletido no ambiente que chamamos de Hospital de Ensino Odontológico (HEO), um centro de excelência entregue à cidade de Porto Alegre no ano de 2016.

A idealização do Hospital surgiu de um sonho antigo que começou a tomar forma na mudança curricular, no período entre os anos de 2002 e 2005. Promoveu-se com isto uma nova forma de pensar e fazer Odontologia em nossa Faculdade. Não mais baseada nas especialidades odontológicas, mas focada em clínicas de complexidade crescente conforme às necessidades de saúde do paciente e do desenvolvimento do aluno. A Odontologia ministrada de uma forma integrada, unindo todos os conteúdos e mudando assim a forma de olhar o paciente. Este, não mais um objeto compartimentalizado de estudo, mas um indivíduo único, tratado na sua totalidade. Esta qualificação do aprender exigiu de nosso corpo docente e técnico um grande esforço, que envolveu desapego e muita abertura para uma forma de trabalho pioneira no Brasil. Rompemos todas as barreiras que se apresentaram. Idealizar um novo espaço de trabalho tornou-se necessário, condizente com esta etapa de mudança e desenvolvimento.

Então, em sequência histórica, concretizamos o projeto do Hospital em 2010 e sua obra civil ocorreu até o ano de 2015. Na etapa final da entrega da obra, a Direção, constituída pelos Professores Pantelis Varvaki Rados e Prof. Régis Burmeister Santos respectivos Diretor e Vice, organizou grupos de trabalho (GTs) para preparar a ocupação efetiva do HEO. A ideia foi utilizar referenciais de qualidade, para que se oportunizasse uma verdadeira mudança de paradigmas neste processo, não só uma simples mudança física 
para um novo espaço de trabalho. Assim, vários GTs, como por exemplo, o de acesso ao hospital, o de gestão de materiais, o de organização da central de material esterilizado, entre outros, trabalharam efetiva e ativamente por aproximadamente 3 semestres. A ocupação do novo espaço iniciou, de forma experimental, em setembro de 2016 e já no primeiro semestre de 2017, praticamente todas as atividades clínicas da Faculdade de Odontologia já se desenvolveram no HEO.

No trabalho junto à Coordenação das Clínicas e agora, junto ao Comitê Gestor do Hospital, venho assistindo uma integração qualificada, de toda nossa comunidade, envolvendo alunos, professores, técnicos e usuários dos nossos serviços.

Todo este processo inovador, que vem ocorrendo nesta última década, constitui um divisor de águas em nossa história: antes e depois da experiência Hospital de Ensino Odontológico. A nova Direção, constituída pelas Professoras Susana Samuel e Deise Ponzoni, respectivamente Diretora e Vice, vem dando continuidade à excelência deste movimento. Temos recebido visitantes de diversos lugares, interessados em conhecer as dependências e os processos relativos ao nosso Hospital. Nossa experiência vitoriosa tem servido de modelo para outras organizações.

Muitas adaptações e convencimentos se fazem ainda necessários em nossos processos de trabalho. Mas ao caminhar pelo espaço do HEO, observo que a etapa mais complexa já foi vencida. Já respiramos os ares da mudança com tranquilidade e certeza de estarmos no caminho certo.

Por fim, temos muitas razões para comemorar estes 120 anos. Muito trabalho nos espera pela frente, mas as conquistas já estão aí, sendo motivo de alegria para todos nós. Nosso currículo novo. O curso noturno já formando suas primeiras turmas. Nossa Pós-graduação de excelência que já é referência mundial. E nosso Hospital de Ensino Odontológico, que vem coroar tudo isto.

Continuemos nosso trabalho árduo rumo à excelência e à qualificação!

Estamos todos de parabéns! Vamos festejar muito!

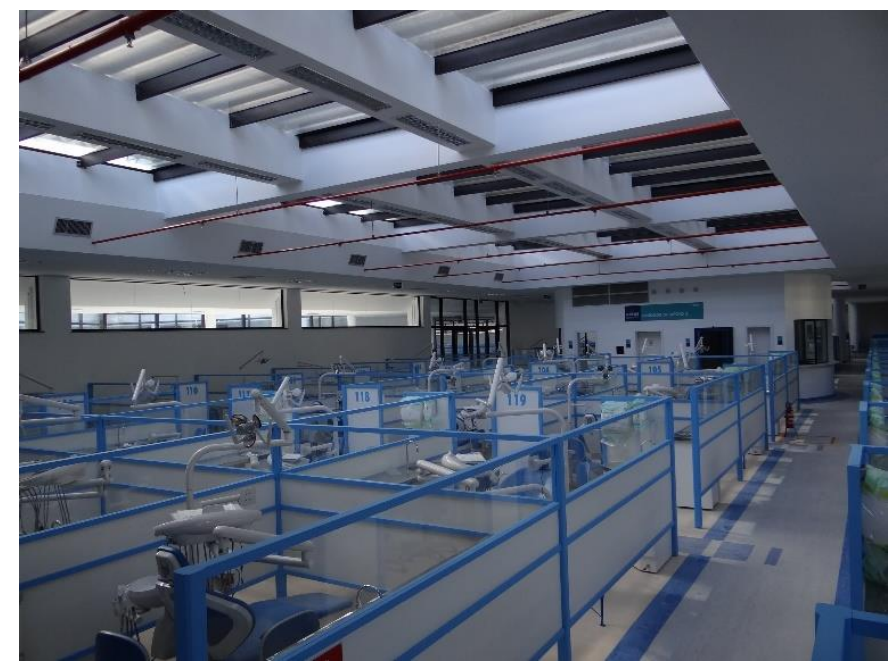

Professora Dra. Berenice Barbachan e Silva Coordenadora do Comitê Gestor do Hospital de Ensino Odontológico Faculdade de Odontologia - UFRGS 